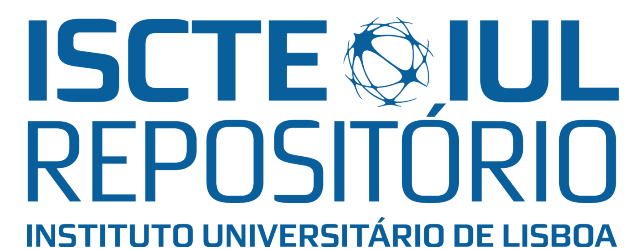

Repositório ISCTE-IUL

Deposited in Repositório ISCTE-IUL:

2021-03-22

Deposited version:

Accepted Version

Peer-review status of attached file:

Peer-reviewed

Citation for published item:

Hannam, K., Butler, G., Witte, A. \& Zuev, D. (2021). Tourist's mobilities: Walking, cycling, driving and waiting. Tourist Studies. 21 (1), 57-69

Further information on publisher's website:

$10.1177 / 1468797621992931$

Publisher's copyright statement:

This is the peer reviewed version of the following article: Hannam, K., Butler, G., Witte, A. \& Zuev, D. (2021). Tourist's mobilities: Walking, cycling, driving and waiting. Tourist Studies. 21 (1), 57-69, which has been published in final form at https://dx.doi.org/10.1177/1468797621992931. This article may be used for non-commercial purposes in accordance with the Publisher's Terms and Conditions for self-archiving.

Use policy

Creative Commons CC BY 4.0

The full-text may be used and/or reproduced, and given to third parties in any format or medium, without prior permission or charge, for personal research or study, educational, or not-for-profit purposes provided that:

- a full bibliographic reference is made to the original source

- a link is made to the metadata record in the Repository

- the full-text is not changed in any way

The full-text must not be sold in any format or medium without the formal permission of the copyright holders. 


\title{
Tourist's Mobilities: Walking, Cycling, Driving and Waiting
}

Kevin Hannam - Pro-Rector (Research) at the University of Saint Joseph, Macau, China; Visiting Researcher, University of Johannesburg, South Africa; Visiting Professor, Nebrija University, Madrid, Spain; Honorary Professor, Technological Higher Education Institute, Hong Kong, China.

Gareth Butler - Senior Lecturer, Flinders University, Adelaide, Australia

Alexandra Witte - Assistant Professor at City University of Macau, China

Dennis Zuev - Assistant Professor at City University of Macau, China and Associate Researcher at CIES-ISCTE, IUL and Instituto Oriente, University of Lisbon, Portugal.

\begin{abstract}
This commentary reviews recent research in terms of tourist's mobilities in terms practices of walking, cycling and driving. It concludes by reflecting on the contemporary lock down of travel in terms of the global pandemic and its consequences for waiting, stillness and immobility - particularly in terms of flying.
\end{abstract}

\section{Introduction}

In their introduction to the inaugural issue of the journal Tourist Studies, Adrian Franklin and Mike Crang (2001) signaled the need for a more theoretically informed study of tourism and tourists influenced, in part, by the so called 'cultural turn' in the social sciences.

Subsequently, the 'mobilities paradigm' was also developed in relation to a renewed interest in theorising various forms of movement, including that of tourists (Sheller and Urry, 2004; Hannam et al. 2006; Hannam, 2008). Indeed, the argument was made that understanding tourism practices becomes more important when it is linked to other forms of mobility rather than less important. Mimi Sheller and John Urry (2004: 1) thus argued that "many different mobilities inform tourism, shape the places where tourism is performed, and drive the making and unmaking of tourist destinations. Mobilities of people and objects, airplanes and suitcases, plants and animals, images and brands, data systems and satellites, all go into 'doing' tourism. ... Tourism mobilities involve complex combinations of movement and stillness, realities and fantasies, play and work."

Furthermore, Peter Adey (2009: 49) notes that: "This is an approach which is not limited to representational thinking and feeling, but a different sort of thinking-feeling altogether. It is a recognition that mobilities... involve various combinations of thought, action, feeling and articulation." Tourism thus offers a range of physical and sensual stimuli that reassert the embodied nature of human life: the warmth of the sun on the face, water lapping around your feet, the increased heart-rate while riding the rollercoaster, the discomfort of the long-haul flight, the upset stomach, the hotel massage, the feelings of being under the influence of alcohol, the bumps of a rickshaw, or even of dancing awkwardly (Hannam and Knox, 2010). In a previous 'state of the art' review of the literature on tourism mobilities, Hannam et al (2014) discussed the various materialities and technologies that inform contemporary tourist's practices. In this commentary we wish to take this further and focus on a number of 
the modalities involved in such practices. Thus, this paper reviews, in turn, tourist's practices of walking, cycling and driving. We conclude by reflecting on the contemporary lock down of travel in terms of the pandemic and its consequences for waiting, stillness and immobility - particularly in terms of flying.

\section{On Your Feet}

Walking is frequently acknowledged as one of the most fundamental forms of human mobility (Ingold and Vergunst, 2016). While often mundane, walking is also a significant practice in leisure and tourism (Hannam \& Witte, 2018). As such, it has garnered increasing attention in tourist studies both as the primary activity pursued by tourists and as a form of active transport to facilitate other activities. In urban contexts, studies have shown that walkability may be a potentially significant factor for visitor experiences (Ujamg \& Muslim, 2014) as tourists often experience specific parts of city landscapes by meandering on foot (Le-Klähn et al., 2015; Thompson and Schofield, 2017). Further, as Davies (2016) reminds us, outdoor activities such as kayaking or mountain climbing often require participants to engage in significant stretches of walking, subsequently contributing to the overall tourist experience. Thus, our understanding of touristic mobilities may benefit from further research into walking as a form of active transport.

A significant body of research has concentrated on tourist's experiences of walking trails, like the Appalachian Trail (e.g. Littlefield \& Siudzinski, 2012), the Inca Trail (e.g. Cutler et al., 2014), the West Highland Path (den Breejen, 2007), or the Camino de Santiago (e.g. Slavin, 2003), investigating issues around environmental impacts, place-making, pilgrimage, walking practices, or walking experiences. Indeed, in terms of pilgrimage or 'sacred mobilities' (Maddrell et al., 2015) a great deal of research has been published in Tourist Studies (see for example, Straub 2016; . From a cultural perspective, several publications have, indeed, moved away from well-trodden paths of Western walking tourism. In the Chinese context, $\mathrm{Li}$ et al. (2019) investigated Chinese tourists' motivation to walk, while Witte (2020) has explored the diversity of domestic walking communities on China's Ancient Tea Horse Road. Equally notable research has been conducted in the context of Korea (e.g. Oh et al., 2019) and Japan (e.g. Kato \& Progano, 2017), as well as in the Middle East, including Mason's work on the Jordan Trail, and Kliot \& Collins-Kreiner's (2018) exploration of the role of nation and place identity on the Israel National Trail.

In terms of tourism mobilities, rhythmanalysis has offered a fruitful avenue of investigation for understanding relationships between recreational walkers, walking experiences, and places (e.g. Küpers \& Wee, 2018; Sarmento, 2016; Stevenson \& Farrell, 2017). As Tim Edensor (2010) outlined, walking practices and values are informed by particular sociocultural discourses and historic contexts. For example, Sarmento (2016) investigated how tourists move through unknown places using rhythmanalysis, finding improvisation to exist alongside patterns of unease and mirroring local rhythms, contributing to place-making. Johinke (2018) discusses the importance of sound in terms of the embodied experience of walking tours. Yet, as Davies (2016) has discussed, current research rarely portrays the diversity of those who walk, their motivations, and practices, potentially challenging the perspective of walking as a primarily Western, white, able-bodied and frequently male pastime. Thus, a further body of research is emerging in relation to women walking alone (Brown et al., 2020; Coble et al., 2003). Brown et al., (2020) highlight how women's experiences of walking on holiday are constrained by their feelings of vulnerability. McAnirlin \& Batts Maddox (2020) recent study on women in co-ed hiking communities 
found they were frequently impacted by gendered assumptions around their skills and fears of safety.

Crucially, as Stanley (2019) has emphasised, little attention has been paid to 'deviant' bodies within walking tourism, whether these are in relation to fat, queer, or ethnic mobilities.

Notable exceptions include Ratna's (2017) research on Indian immigrants in Britain and their relationship to walking for leisure, where leisure walks were a way for participants to engage in social encounters, but also to take 'ownership' of the places they walked and experiencing these as home. Moreover, Stanley's (2019: 14) exploration of female, fat, queer, and coloured bodies' representations on Instagram walking communities in North America offers valuable insights into mobilities systems that "erase and/or limit the agency and visibility of nontraditional outdoorspeople."

\section{On Your Bike}

Like walking, cycling tourism can contribute to health and well-being, but also has environmental benefits and positive impacts facilitating intimate contact with nature and contact with local population, as well as access to the places off the beaten track or remote territories (Gazzola et al. 2018). Cycling tourism can be of several modalities: long distance autonomous self-propelled touring, long-distance package cycling tours, short distance exploration of urban sites and rurality. These modalities also vary according to the twowheeler used (e-bike, touring bike, mountain bike etc.). Until recently, there has been relatively little research on touring cultures and the embodied experiences of cycling tourists (Spinney, 2006; Liu et al., 2018). A characteristic feature of independent cycling tourism is that cyclists use their own bicycles and other gear for (or when) transiting to the destination and moving through the destination. However, it is also possible for many mass tourists to fit an autonomous cycling trip into their vacations and thus shift gears in their vacationing rhythm. Cycling tours may be organized along iconic trails or cycleways (Bonham and Cox, 2010), and whole regions can be promoted for cycling tourist exploration.

However, while some cities and countries, such as The Netherlands, may promote the use of bicycles, most national policies are ambivalent in treating cyclist tourists as legitimate travellers. Before mass car-based mobilities, the bicycle was often used in combination with rail transport (Lamont and Buultjens, 2011). However, common understanding of public transport and cycling combination is far from uniform even in Europe. It is nearly impossible to carry a bike on a long-distance bus, except if packed in a box and success depends very much on the negotiations with the bus-driver. Carrying a bike on a suburban train in Germany is still relatively costly, while in UK or Portugal it is relatively easy and free of charge. The space for cyclists on the train is however limited. Although in Austria there are dedicated carriages with bike-racks, on the other hand Austria does not allow mountain biking on forest roads. These mobilities and tensions are part of the development of cycling societies, where multiple obstacles are created for cycling accessibility (Zuev et al. forthcoming). Nevertheless, the promotion of cycling as a way to explore the country is increasingly seen as a sustainable, romantic and equitable way of exploring rural landscapes. While bicycle tourism in rural settings has led to a revitalization and diversification of regional economies (Ritchie and Hall, 1999), urban cycling as a part of the tourist experience and the creation of a cycling infrastructure as an attempt to boost the city image is often seen ambivalently and problematically.

With the renaissance of urban cycling and the use of bicycles for leisure and recreation 
moving on two-wheels in the city has become a part of the urban tourist experience, where numerous public (e)bike-sharing schemes and e-scooter sharing has arguably allowed for the development of a slower mobility perspective of the urban landscape. This has also brought issues of urban touristification, whereby infrastructure is created not necessarily to solve urban problems but to attract new kinds of (wealthy) tourists and residents and create a more attractive, liveable city image (Zuev et al. forthcoming). This micro-mobility - that is the use of electric two-wheelers (scooters, bikes and e-bikes) has the potential to increase sustainable urban mobility and is actively used by tourists in popular tourist destinations, such as Vienna, Lisbon and Paris. Yet, very little is known about how tourists actually use and employ diverse public-sharing schemes related to micro-mobility. In terms of cycling cultures, Jungnickel and Aldred (2014) highlight how cyclists mediate their exposure to urban environments using technologies such as mobile audio devices. The proliferation of new forms of urban mobility thus demands attention not only for how planners might solve the tourist mobility problems but how the city is experienced differently by tourists, and how these new mobility practices affect the local population such as the overcrowding of public space.

Essentially, cycling and new modes of micro-mobility allow for a better analysis of how places are experienced in terms of different speeds, landscapes, sounds and rhythms (Jungnickel and Aldred, 2014; Cook and Edensor, 2017; Popan, 2020). While the destination itself can be the same, the embodied experience of its different rhythms, landscapes, sounds and speeds may also add a different dimension to a tour in terms of social interaction with others (McIlvenny, 2015). Cycling as a mode of slow tourism is gaining popularity and in some tourist sites the cycle rickshaw as a traditional mode of transportation has been preserved as a part of the local identity and as a symbol of the slow past evoking nostalgic memories (see photo 1 below).

Photo 1. Cycle rickshaws in Macau, 2020.

\section{In Your Car}

The role of the car in amplifying tourists' desires for a range of experiences and emotions to be felt has been discussed at considerable length in tourism research. Many of these research directions examine the paradoxical challenges tourists automobilties present, most notably when car users increase in number and automobility vectors intersect with other modalities. As Beckmann (2004: 83) posited, the car has a tendency to turn in on itself, and as such, "enables and disables, individualizes and reintegrates, liberates its users from one autocentred spatio-temporality and coerces them into another." Indeed, the act of driving, and the original promises of the motor car, including its ability to prompt feelings of independence, escapism, and control (see Butler \& Hannam, 2012; Gilbert \& Abdullah, 2004; Hagman, 2010; White \& White, 2004), are set to be further eroded by growing numbers of car users. Consequently, future tourist automobilities may involve banal practices and mundane performances with greater regularity, as drivers must negotiate growing traffic jams and the increasingly restrictive structured systems of the road both en route and at the destinations they visit (see Dickinson et al., 2009; Edensor, 2007; Featherstone, 2004; Hannam et al., 2014; Sheller, 2004; Urry, 2004; 2007). These risks extend further to self-drive tourists, especially international tourists, that must negotiate unfamiliar environs, contrasting landscapes, and road rules and regulations, that significantly contrast those from home (see Wu, 2015; Wu \& Pearce, 2014). In his recent paper on 'speed tourism' Matthias Gross (2020: 
298) thus discusses the paradoxical environment of the German autobahn in terms of its "unruliness in relation to strict rules" for tourists. Moreover, the challenges associated with competing automobilities are of particular relevance during the continuation of the COVID19 pandemic, as cars have at least temporarily emerged as a preferred - and safer - vehicle in which to travel (see Aaltola, 2012; Page et al., 2012; Wikswo et al., 2011).

How technological advancements will further change or modify driving experiences and impact upon the 'multi-sensory practices of tourism mobilities' (Wilson \& Hannam, 2017: 26), are presenting new opportunities for research. These directions include not only the hybrid communication technologies that are embedded within new motor vehicles but also the 'disruptive impacts' of Electric Vehicles (EVs) and the nearing age of Autonomous Vehicles (AVs) (Prideaux \& Yin, 2019: 459). Indeed, Featherstone's (2004: 2) notion of automobility, that framed car journeys as 'modes of autonomous, self-directed movements' is set to be significantly challenged as the emergence of AVs will move us further away from the conventional automobilities of the $20^{\text {th }}$ and early $21^{\text {st }}$ centuries. Although both AVs and EVs have been favourably positioned in contemporary discourse because of their potential to help offset carbon emissions and improve road safety, limited attention has so far been afforded toward how these vehicles may enhance or inhibit the experience of automobility (Prideaux \& Yin, 2019; Wadud, MacKenzie, \& Leiby, 2016). This is perhaps surprising given that the development of AVs and EVs will most likely shift how drivers' and passengers" "different embodied engagements with the car" are felt and experienced (Merriman, 2009: 590). AVs will undoubtedly challenge feelings of autonomy and genuine control as the car 'driver' cedes further agency to the car itself. Similarly, the ability of the motor car in enabling a range of sensations or 'sensecapes' to be experienced (see Hannam, et al. 2006; Merriman, 2009; Larsen, Urry, \& Axhausen, 2007; Sheller, 2004; Trauer \& Ryan, 2005), may also be hindered by EVs, as the sounds and sensations afforded by petrol and diesel engine cars will be eventually diluted or even lost. As Wilson and Hannam (2017: 33) observed, the conditions of the road can lead to "sonic mobilities" that influence how landscapes are negotiated as drivers become "embedded within the environment by the ways in which they attempted to move with and through it." Indeed, motor vehicles do much more than simply move us along roads but enable us to feel them in unique ways too.

Broz and Habeck (2015) depict the hybrid relations of humans and non-humans held by the car. Furthermore, the balance between human and artificial inputs, as well as the impacts these inputs will have on feelings of control, appears to be delicately poised even if advancements in inbuilt car technologies have frequently been championed as positive and empowering developments from the perspective of the driver (see Dickinson et al, 2013; Germann Molz, 2012; Gretzel, 2010; Wang, Xiang, \& Fesenmaier, 2016). Although Global Positioning Systems (GPS) may guide the driver through alien landscapes or urban entanglements (see Lamsfus, et al., 2015; Merriman, 2009; Wang et al., 2012; Wang, Xiang, $\&$ Fesenmaier, 2016) or aid the driver in finding solutions to practical problems along road trips (Gretzel, 2010), these technologies may also inhibit feelings of control and autonomy. Moreover, cars now host with increasing frequency a range of external mobile communication technologies that are brought on-board by drivers and their passengers. Just as they do when used beyond the confines of the car, these technologies permit occupants to make informed decisions about where to go or what to do and ease the processes of travel though unfamiliar locations (see Dickinson et al., 2013; Gretzel, 2010; Moore et al., 2012; Pearce et al., 2015; Neuhofer, 2016; Paris, et al., 2015). Thus, whilst mobile communication technologies may help tourists make better-informed decisions, they also may dilute the complexities (and joys) of decision-making processes associated with travel and adventure 
(Butler \& Szili, 2020; Neuhofer, 2016; Paris et al., 2015). Moreover, automobility performances that are heavily infused with technological inputs may impede the car users' opportunities to reveal knowledge and 'geographical competencies' that can foster feelings of enjoyment and satisfaction (Binnie et al., 2007, p. 166). Nevertheless, motor cars, as Merriman (2009: 591) suggests can still provide "a mobile, personal, private enveloped space amid the public spaces of the street and road" that in turn permit flexible, driving pleasures to emerge as the driver can transport, interact and 'hang out' with friends and family whilst being on the move. Thus, tourist's car use, even in the future, may truly encapsulate Urry's (2007) positioning of private vehicles as domestic modes of dwelling that enable new leisure performances to be imagined and realised.

\section{Waiting to Fly}

For most non-elite travellers, flying involves a great deal of waiting around. Checking in at least two hours prior to departure and sitting in specific 'waiting' areas, waiting for announcements. Waiting has been described by Gasparini (1995) as an annoying experience that may turn into an intolerable one, which at the same time engenders the virtue of patience, which implies giving value to slowing down. David Bissell (2007) reminds us that waiting has been long neglected as a frequent and often inevitable experience of mobile everyday life. Every period of stillness contains the possibility of rupture or suspension suggesting that waiting is not a slowed down rhythm, but instead an "incipient rich duration" (Bissell, 2007: 279). However, with the advent of the Covid-19 global pandemic this waiting has become much more pronounced as whole countries have entered lock-downs to prevent the spread of the virus. While some "rapid assessments" of the impacts of Covid-19 on tourism have already been published by scholars (Gossling et al., 2020; Sigala, 2020), it has also been recognised that the deep stasis and stillness has engendered anxious immobilities (Zuev and Hannam, 2020). Zuev and Hannam $(2020,4)$ argue that "the state of contagion is characterized by ambivalence of "waiting it out", a different modality of waiting - less passive, but with imposed restrictions on activities, thus actively waiting it out or reinventing the durational impasse through the modification and adaptation of daily rhythms." In 2010 the volcanic eruption in Iceland resulted in over ten million flight passengers becoming stranded with air routes disrupted for several weeks (Birtchnell and Buscher, 2010). The impact of the Covid-19 virus on aeromobilities has been even more significant, with many tourists literally waiting to fly.

\section{Future Research Directions}

Pursuing inquiries into walking or cycling as forms of active transport can further our insights into tourists' mobility choices and experiences within destinations. Additionally, while recent publications have signalled a shift in geographical concentrations of walking and cycling tourism and leisure research from predominantly Western contexts, further research within non-Western cultural contexts is needed. Diverse perspectives of frequently ignored, silenced and side-lined walkers and cyclists, including solo female bodies, fat bodies, queer bodies, and ethnicities need to be included. Understanding the practices and experiences of unlikely walkers and cyclists (Stanley 2019; den Hoed and Jarvis, 2021) can lead not only to a better understanding of the potential barriers to participation in exercise, but also offer new avenues to explore how places are encountered, made and re-made in terms of wider theories of tourism mobilities. 
The legacies of COVID-19 will also continue to affect tourism mobilities move even after the eventual cessation of the pandemic. It is to be anticipated that public confidence in using larger-scale modes of transport, such as airplanes (aeromobilities) and cruise ships (aquamobilities), as well as the heavily populated moorings they connect to, will take time to rebuild. When considering that tourist automobilities have already been framed as pragmatic and 'safer' alternatives peri-COVID-19, and may continue to be perceived in this way if and when the pandemic is more effectively managed - or eradicated - new automobility challenges will undoubtedly emerge. Moreover, increased road use may impede the safety and wellbeing of self-drive tourists or pedestrians, and it is therefore critical that new studies further examine the paradoxical nature of the car's ability to both support and inhibit the safeties of those that are exposed to car spaces during post-COVID19 times.

Finally, research also needs to consider the increased digitisation of tourism mobilities. We are increasingly sharing data (whether we know it or not), especially visual records about our travelling. And while some cities are trying to campaign against "selfies" and "hashtagging" (see Zuev and Bratchford 2020) they are themselves involved in creating visual experiences for tourists to erleben (to live through) in a different way and record it. These recordings and image-streams are flowing vast distances, they reveal features about our close and distant others, our food habits and places we visit and enjoy. We will arguably start to co-imagine our travel with smart algorithms and machines that already learn faster than we think about what we think.

\section{References}

Aaltola, M. (2012). Contagious insecurity: War, SARS and global air mobility. Contemporary Politics, 18, 53-70.

Adey, P. (2009). Mobility. London: Routledge.

Beckmann, J. (2004). Mobility and Safety. Theory, Culture \& Society, 21(4-5), 81-100.

Binnie, J., Edensor, T., Holloway, J., Millington, S., \& Young, C. (2007). Mundane mobilities, banal travels. Social \& Cultural Geography, 8(2), 165-174.

Birtchnell, T. and M. Buscher. (2011). Stranded: An Eruption of disruption. Mobilities, 6(1): $1-9$.

Bissell, D. (2007). Animating Suspension: Waiting for Mobilities. Mobilities 2(2): 277-298

Bonham, J, and P. Cox (2010). The disruptive traveller? A Foucauldian analysis of cycleways. Road \& Transport Research. 19(2): 42-53.

Brown, L., de Coteau, D. \& Lavrushkina, N. (2020). Taking a walk: The female tourist experience. Tourist Studies, 20(3), 354-370.

Broz, L. and Habeck, J. (2015). Siberian automobility boom: From the joy of destination to the joy of driving there. Mobilities, 10(4), 552--570 
Butler, G., \& Hannam, K. (2012). Independent tourist's automobilities in Norway. Journal of Tourism and Cultural Change, 10(4), 285-300.

Butler, G. and Szili, G. (2020). Mediating technologies on the move: tourists' automobilities through the Limestone Coast, South Australia. Asia Pacific Journal of Tourism Research. 25(4), 369-381.

Cook, M. and Edensor, T. (2017). Cycling through dark space: Apprehending landscape otherwise. Mobilities, 12(1), 1-19.

Davies, N. (2016). Who walks, where and why? Practitioners' observations and perspectives on recreational walkers at UK tourist destinations. Annals of Leisure Research, 21(5), 553574.

Davies, N., L. Blazejewski, and G. Sherriff (2020) The rise of micromobilities at tourism destinations. Journal of Tourism Futures, 6(3), 209-212.

den Hoed, W. and Jarvis, H. (2021). Normalising cycling mobilities: an age-friendly approach to cycling in the Netherlands. Applied Mobilities, DOI: 10.1080/23800127.2021.1872206

Dickinson, J. E., Filimonau, V., Cherrett, T., Davies, N., Norgate, S., Speed, C., \& Winstanley, C. (2013). Understanding temporal rhythms and travel behaviour at destinations: Potential ways to achieve more sustainable travel. Journal of Sustainable Tourism, 21(7), 1070-1090.

Dickinson, J. E., Robbins, D., \& Fletcher, J. (2009). Representation of transport. Annals of Tourism Research, 36(1), 103-123.

Edensor, T. (2007). Mundane mobilities, performances and spaces of tourism. Social \& Cultural Geography, 8(2), 201-215.

Edensor, T. (2010). Walking in rhythms: Place, regulation, style and the flow of experience. Visual Studies, 25(1), 69-79.

Featherstone, M. (2004). Automobilities: An introduction. Theory, Culture \& Society, 21(45), 1-24.

Franklin, A. and Crang, M. (2001). The. Trouble with Tourism and Travel Theory. Tourist Studies, 1(1), 5-22.

Gasparini, G. (1995). On Waiting. Time and Society. 4(1): 29-45.

Germann Molz, J. (2012). Travel connections: Tourism, technology and togetherness in a mobile world. London: Routledge.

Gilbert, D. and Abdullah, J. (2004). Holiday taking and the sense of well-being. Annals of Tourism Research, 31(1), 103-121. 
Gössling, S., D. Scott and C. M. Hall (2020). Pandemics, tourism and global change: a rapid assessment of COVID-19, Journal of Sustainable Tourism, DOI:

10.1080/09669582.2020.1758708

Gretzel, U. (2010). Travel in the network: Redirected gazes, ubiquitous connections and new frontiers. In M. Levina \& G. Kien (Eds.), Post-global network and everyday life (pp. 4158). New York: Peter Lang.

Gross, M. (2020). Speed Tourism: The German Autobahn as a tourist destination and location of 'unruly rules'. Tourist Studies, 20(3), 298-313.

Hagman, O. (2010). Driving pleasure: A key concept in Swedish car culture. Mobilities, 5(1), 25-39.

Hannam, K. (2008). Tourism Geographies, Tourist Studies and the turn towards Mobilities. Geography Compass, 2(1), pp.127-139.

Hannam, K., Sheller, M., \& Urry, J., (2006). Editorial: Mobilities, Immobilities and Moorings. Mobilities, 1(1), 1-22.

Hannam, K. \& Knox, D. (2010). Understanding tourism: A critical introduction. London: Sage.

Hannam, K., Butler, G., \& Paris, C. M. (2014). Developments and key issues in tourism mobilities. Annals of Tourism Research, 44, 171-185.

Hannam, K. and Witte, A. (2018). Theorising practices of walking in tourism. In: James, L., Ren, C., \& Halkier, H. (eds). Theories of practice in tourism. London: Routledge.

Ingold, T. and Vergunst, J. (eds.) (2016). Ways of Walking: Ethnography and practice on foot. London: Routledge.

Johinke, R. (2018). Take a walk on the wild side: Punk music walking tours in New York City. Tourist Studies, 18(3), 315-331.

Jungnickel, K. and Aldred, R. (2014). Cycling's sensory strategies: How cyclists mediate their exposure to the urban environment. Mobilities, 9(2), 238-255.

Kato, K. and Progano, R.N., (2017). Spiritual (walking) tourism as a foundation for sustainable destination development: Kumano-kodo pilgrimage, Wakayama, Japan. Tourism Management Perspectives, 24, 243-251.

Kliot, N. and Collins-Kreiner, N. (2018). Social world, hiking and nation: the Israel National Trail. Social \& Cultural Geography, 21(6), 810-838.

Küpers, W. and Wee, D. (2018). Tourist cities as embodied places of learning: walking in the "feelds" of Shanghai and Lisbon. International Journal of Tourism Cities, 4(3), 376-390.

Lamont, M. and J. Buultjens (2011) Putting the brakes on: impediments to the development of independent cycle tourism in Australia. Current Issues in Tourism. 14(1):57-78. 
Lamsfus, C., Wang, D., Alzua-Sorzabal, A., and Xiang, Z. (2015). Going mobile: Defining context for on- the-go travelers. Journal of Travel Research, 54(6), 691-701.

Larsen, J., Urry, J., and Axhausen, K. W. (2007). Networks and tourism: Mobile social life. Annals of Tourism Research, 34(1): 244-262.

Le-Klähn, D. T., Roosen, J., Gerike, R., and Hall, C. M. (2015). Factors affecting tourists' public transport use and areas visited at destinations. Tourism Geographies, 17(5), 738-757.

Li, P., Ryan, C. and Bin, Z. (2019). The motivations of Chinese hikers: data from Ningbo. Current Issues in Tourism, 23, 2893-2909.

Littlefield, J., and Siuzinski, R. A. (2012). 'Hike your own hike': Equipment and serious leisure along the Appalachian Trail. Leisure Studies, 31(4), 465-486.

Liu, G., Krishnamurthy, S. and van Wesemael, P. (2018). Conceptualizing cycling experience in urban design research: A systematic literature review. Applied Mobilities, DOI: $\underline{10.1080 / 23800127.2018 .1494347}$

Maddrell, A., Terry, A. and Gale, T. (eds.) (205). Sacred Mobilities. London: Routledge.

Mason, O. (2020). Walking the line: lines, embodiment and movement on the Jordan Trail. Cultural Geographies, 27(3), 395-414.

McAnirlin, O.\& Maddox, C. (2020). 'We have to be a little more realistic': women's outdoor recreation experiences in a community hiking group. Annals of Leisure Research, DOI: $\underline{10.1080 / 11745398.2020 .1820880}$

McIlvenny, P. (2015). The joy of biking together: Sharing everyday experiences of velomobility. Mobilities 10(1), 5655-82.

Merriman P. (2007). Driving Spaces: A Cultural-historical Geography of England's M1 Motorway. Oxford: Blackwell.

Moore, K., Smallman, C., Wilson, J., and Simmons, D. (2012). Dynamic in-destination decision-making: An adjustment model. Tourism Management, 33(3), 635-645.

Neuhofer, B. (2016). Value co-creation and co-destruction in connected tourist experiences. In I. Tussyadiah and A. Inversini (Eds.), Information and communication technologies in tourism (pp. 779-792). New York: Springer.

Oh, M., Kim, S., Choi, Y. and Pratt, S. (2019). Examination of benefits sought by hiking tourists: a comparison of impact-range performance analysis and impact asymmetry analysis. Asia Pacific Journal of Tourism Research, 24(8), 850-864.

Page, S., Song, H. and Wu, D. C. (2012). Assessing the Impacts of the Global Economic Crisis and Swine Flu on Inbound Tourism Demand in the United Kingdom. Journal of Travel Research, 51(2), 142-53. 
Paris, C. M., Berger, E. A., Rubin, S., and Casson, M. (2015). Disconnected and unplugged: Experiences of technology induced anxieties and tensions while traveling.

In I. Tussyadiah \& A. Inversini (Eds.), Information and communication technologies in tourism (pp. 803-816). Vienna: Springer.

Popan, C. (2020) Beyond utilitarian mobilities: cycling senses and the subversion of the car system, Applied Mobilities, 5(3), 289-305.

Prideaux, B., and Yin, P. (2019). The disruptive potential of autonomous vehicles (AVs) on future low-carbon tourism mobility. Asia Pacific Journal of Tourism Research, 24(5), 459467.

Ratna, A. (2017). Walking for leisure: the translocal lives of first generation Gujarati Indian men and women. Leisure Studies, 36(5), 618-632.

Ritchie, B.W. and C. M. Hall (1999) Bicycle Tourism and regional development: A new Zealand Case study. Anatolia: An International Journal of tourism and hospitality research. 10(2), 89-112.

Sarmento, J. (2016). Tourists' walking rhythms: 'doing' the Tunis Medina, Tunisia. Social \& Cultural Geography, 18(3), 295-314.

Sheller, M. (2004). Automotive emotions: Feeling the car. Theory, Culture \& Society, 21(45): 221-242.

Sheller, M. and Urry, J. (eds.) (2004). Tourism Mobilities. London: Routledge.

Sigala, M. (2020). Tourism and COVID-19: Impacts and implications for advancing and resetting industry and research, Journal of Business Research, 117, 312-321.

Slavin, S. (2003). Walking as spiritual practice: The pilgrimage to Santiago de Compostela. Body \& Society, 9(3), 1-18.

Spinney, J. (2006) A place of Sense: a kinaesthetic ethnography of cyclists on Mount Ventoux. Environment and Planning D: Society and Space. 24: 709-732.

Stanley, P. (2019). Unlikely hikers? Activism, Instagram, and the queer mobilities of fat hikers, women hiking alone, and hikers of colour. Mobilities, 15(2), 241-256.

Stevenson, N. and Farrell, H. (2017). Taking a hike: exploring leisure walkers embodied experiences, Social \& Cultural Geography, 19(4), 429-447.

Straub, L. (2016). Negotiation and experience: Space and place in religious pilgrimage. Tourist Studies, 16(1), 88-104.

Thompson, K., \& Schofield, P. (2007). An investigation of the relationship between public transport performance and destination satisfaction. Journal of Transport Geography, 15(2), $136-144$. 
Trauer, B., \& Ryan, C. (2005). Destination image, romance and place experience - an application of intimacy theory in tourism. Tourism Management, 26, 481-491.

Ujang, N., \& Muslim, Z. (2014). Walkability and attachment to tourism places in the city of Kuala Lumpur, Malaysia. Athens Journal of Tourism, 2(1), 53-65.

Urry, J. (2004). The ‘system’ of automobility. Theory, Culture \& Society, 21(4-5), 25-39.

Urry, J. (2007). Mobilities. Cambridge: Polity.

Wadud, Z., MacKenzie, D. and Leiby, P. (2016). Help or hindrance? The travel, energy and carbon impacts of highly automated vehicles. Transportation Research Part A, 86, 1-18.

Wang, D., Xiang, Z., and Fesenmaier, D. R. (2016). Smartphone use in everyday life and travel. Journal of Travel Research, 55(1), 52-63.

White, N. R. and White, P. B. (2004). Travel as transition: Identity and place. Annals of Tourism Research, 31(1), 200-218.

Wikswo M. E., Cortes, J., Hall, A. J., Vaughan, G., Howard, C., Gregoricus, N., \& Cramer, E. H. (2011). Disease transmission and passenger behaviors during a high morbidity Norovirus outbreak on a cruise ship. Clinical Infectious Diseases, 52, 1116-1122.

Wilson, S. and Hannam, K. (2017). The frictions of slow tourism mobilities: Conceptualising campervan travel. Annals of Tourism Research, 67, 25-36.

Witte, A. (2020). “Chinese don't walk?" - The emergence of domestic walking tourism on China's Ancient Tea Horse Road. Journal of Leisure Research, DOI: $\underline{10.1080 / 00222216.2020 .1847624}$

Wu, M.-Y. (2015). Driving an unfamiliar vehicle in an unfamiliar country: Exploring Chinese recreational tourists' safety concerns and coping techniques in Australia. Journal of Travel Research, 54(6), 801-813.

Wu, M.Y. and Pearce, P. L. (2014). Chinese recreational vehicle users in Australia: a netnographic study of tourist motivation. Tourism Management, 43, 22-35.

Zuev, D. and Bratchford, G. (2020). The citizen drone: protest, sousveillance and droneviewing, Visual Studies, DOI: 10.1080/1472586X.2020.1843285

Zuev, D. and Hannam, K. (2020). Anxious Immobilities: An ethnography of coping with contagion (Covid-19) in Macau. Mobilities, DOI: 10.1080/17450101.2020.1827361

Zuev, D., Psarikidou, K. and C. Popan (2021) Cycling Societies: Innovations, Inequalities and Governance. London: Routledge. 